\title{
PENGARUH IKLIM ORGANISASI DAN KOMITMEN ORGANISASI TERHADAP ORGANIZATIONAL CITIZENSHIP BEHAVIOR (OCB) PEGAWAI DI LINGKUNGAN DINAS PENDIDIKAN KOTA TANGERANG PROVINSI BANTEN
}

\begin{abstract}
Shintawati ${ }^{1}$
Abstract: The objective of this research is to study information about the effect of organizational climate and organizational commitment on employe's citizenship behavior (OCB). This research by using survey method with path analysis applied in testing hypothesis. The sample size in this research was done to 65 employe's with samples taken using simple random sampling. The data were analyzed by using descriptive analyses, regressive analysis, and line analysis method. The result shows that there are direct influence of the followings: (1) there is a positively direct effect of organizational climate on employe's organizational citizenship behavior (OCB). .(2) there is a positively direct effect of organizational commitment on employe's organizational citizenship behavior $(O C B)$. (3) there is a positively direct effect of organizational climate on organizational commitment.It is expected that the results of the research could be implied in increasing and optimalizing employe's organizational citizenship behavior (OCB), organizational climate and organizational commitment should be taken into account.
\end{abstract}

Keywords: organizational climate, organizational commitment, organizational citizenship behavior (OCB).

\section{PENDAHULUAN}

Dinas Pendidikan Kota Tangerang adalah salah satu dinas yang dibentuk oleh Kota Administratif Tangerang berdasarkan Peraturan Daerah Tingkat II Tangerang. Dinas Pendidikan merupakan lembaga yang sangat penting karena sebagai lembaga pendidikan yang mampu memfasilitasi para pegawai sebagai salah satu faktor penentu perkembangan sumber daya manusia (SDM). Di mana mutu sumber daya manusia (SDM) berpengaruh positif dengan mutu pendidikan, mutu pendidikan sering diindikasikan dengan kondisi yang baik, memenuhi syarat, dan segala komponen yang harus terdapat dalam pendidikan. Pemberitaan tentang buruknya pelayanan pegawai pada suatu instansi. Pasalnya para pegawai, dinilai kurang memiliki loyalitas, sehingga mempengaruhi perilaku positif para pegawai. Kondisi tersebut memperlihatkan bahwa walaupun ada kenaikan dari gaji pegawai tetapi pelayanan publik masih buruk perilaku positif pegawai tidak terlihat karena kesadaran diri pegawai belum terbentuk, sektor pendidikan menjadi sorotan dalam hal perilaku pelayanan masyarakat.

Kondisi tersebut disebabkan oleh kurang baiknya sistem pelayanan yang ada pada Dinas Pendidikan Kota Tangerang serta masih rendahnya perilaku keanggotaan organisasional/organizational citizenship behavior (OCB) yang merupakan bagian dari

\footnotetext{
${ }^{1}$ PNS dpk pada SMP Muhammadiyah 3 Kota Tangerang Provinsi Banten dan Kepala SMK Muhammadiyah 2 Kota Tangerang.
} 
perilaku sukarela pegawai Dinas Pendidikan Kota Tangerang. Perilaku keanggotaan organisasional/organizational citizenship behavior (OCB) pegawai Dinas Pendidikan yang masih rendah ini ditunjukkan dengan kurangnya motivasi pegawai dalam melakukan perilaku yang melampaui tugasnya di setiap bidang khususnya dalam melayani para kepala sekolah atau tenaga pendidik dalam hal ini adalah guru-guru di kota Tangerang baik berstatus negeri atau swasta. Para pegawai lebih banyak melakukan perilaku yang melampaui tugasnya dalam keadaan terpaksa dan bukan karena kesadaran secara keinginan sendiri atau sukarela untuk mutu dan kualitas pelayanan Dinas Pendidikan. Keadaan dan kondisi seperti ini terlihat sekali ketika suasana dan iklim di dalam organisasi tersebut semakin mendukung para pegawai untuk tidak melakukan perilaku keanggotaan organisasional/organizational citizenship behavior (OCB) serta didukung oleh pelaksanaan sistem penghargaan yang tidak merata/tidak berjalan baik sehingga komitmen diri pegawai mengalami pergeseran maka secara otomatis keterlibatan diri dan keterikatan diri pegawai berkurang dan berpengaruh langsung terhadap perilaku positif pegawai.

Peningkatan mutu pendidikan merupakan faktor penting dalam perbaikan kualitas pendidikan yang harus dilakukan oleh Dinas Pendidikan Kota Tangerang dalam memberikan pelayanan yang terbaik. Dengan memperhatikan dan memanfaatkan potensi yang ada pada para pegawai, perlu digali dan ditumbuhkan, dikembangkan serta ditingkatkan kemampuannya agar pengetahuan dan keterampilan mereka meningkat, sehingga akan mampu melaksanakan tugas-tugas yang menjadi tanggung jawabnya secara efektif dan efisien,serta melakukan pekerjaan yang melampaui tugasnyasecara sukarela karena keterikatan dirinya dengan Dinas Pendidikan Kota Tangerang maka dengan sendirinya dapat meningkatkan kualitas dari perilaku keanggotaan organisasional/organizational citizenship behavior (OCB) para pegawai.

\section{Perilaku $O C B$}

Ricky W Griffin dan Gregory Moorhead (2007:76)" organizational citizenship refers to the behavior of individuals who make a positive overall contribution to the organization." Keanggotaan organisasi mengacu pada perilaku individu yang memberikan kontribusi positif untuk organisasi secara menyeluruh. Colquitt, Lepine dan Wesson (2009:41)"citizenship behavior which is defined as voluntary employee activities that may or may not be rewarded but the contribute to the organization by improving the overall quality of the setting in which work takes place". Perilaku keanggotaan organisasional/organizational citizenship behavior (OCB) didefinisikan sebagai kegiatan karyawan yang dilakukan secara sukarela yang mungkin atau tidak mungkin dihargai tetapi berkontribusi terhadap organisasi dengan meningkatkan kualitas keseluruhan dari tempat dimana pekerjaan berlangsung. Diperkuat kembali McShane dan Von Glinow (2010:17) perilaku keanggotaan organisasional/organizational citizenship behavior (OCB) adalah, "organizational citizenship behavior $(O C B)$ is various forms of cooperation and helpfulness to others that support the organization's social and psychological context". Organizational citizenship behavior (OCB) adalah berbagai kerjasama dan sikap menolong orang lain yang mendukung konteks organisasi sosial dan psikologis. Kreitner dan Kinicki (2011:174) menyatakan perilaku keanggotaan organisasional/organizational citizenship behavior (OCB) adalah: Organizational citizenship behavior (OCB) consist of employees behavior that are beyond the call of duty. Examples include "such as gestures as constructive statements about the department, expression of personal interest in the work of others, suggestions 
for improvement, training new people, respect for the spirit as well as the letter of housekeeping rules, care for organizational property, and punctuality and attendance well beyond standard or enforceable levels. Perilaku keanggotaan organisasional/organizational citizenship behavior (OCB) terdiri dari perilaku individu diluar tugas pekerjaannya. Seperti memberikan saran yang membangun, membantu meningkatkan sumber daya manusia, mengarahkan karyawan baru, menghormati ketentuan-ketentuan organisasi, peduli terhadap property organisasi serta berperilaku melebihi tingkat standar yang ditetapkan.

Selain peran yang melampaui "panggilan tugas", Dimensi dari perilaku keanggotaan organisasional/organizational citizenship behavior (OCB) yang tidak mengikat dan dilakukan dengan sukarela tanpa mengharapkan penghargaan. Penjelasan Griffin dalam Gina Ghania (2004:28) mengenai Perilaku keanggotaan organisasional/organizational citizenship behavior (OCB) adalah perilaku individu yang memberikan kontribusi keseluruhan yang positif kepada organisasi.

Menurut Organ dalam Steve M. Jex and Thomas W. Britt (2008:117), diperkuat lagi Organ (1994) dalam Gina Ghania maka Fred Luthan mengemukakan lima dimensi dari OCB, "Dalam Perilaku keanggotaan organisasional/organizational citizenship behavior (OCB) dibangun dari lima dimensi yang masing-masing memiliki perbedaan,yaitu:(1)Altruism, kesediaan untuk menolong rekan kerja dalam menyelesaikan pekerjaanya dalam situasi yang tidak biasa.(2) Courtesy, perilaku meringankan problem-problem yang berkaitan dengan pekerjaan yang dihadapi orang lain.(3) Sportmanship, menggambarkan pekerja yang lebih menekankan untuk memandang aspek-aspek positif dibanding aspek-aspek negatif dari organisasi, sportmansip menggambarkan sportivitas seorang pekerja terhadap organisasi.(4) Conscientiousness, menggambarkan pekerja yang melaksanakan tugas dan 4 
tanggung jawab lebih dari apa yang diharapkan.(5) Civic virtue, menyangkut dukungan pekerja atas fungsi-fungsi administratif dalam organisasi.

Sintesis dari perilaku keanggotaan organisasional/organizational citizenship behavior $(O C B)$ adalah suatu tindakan anggota organisasi yang muncul secara sukarela melampaui tugasnya dan bukan merupakan tanggung jawabnya tanpa mengharapkan imbalan, bersikap sopan santun, dan memberikan kontribusi demi kebaikan organisasinya.

\section{Iklim Organisasi}

Menurut Fred Luthans (2011:72), iklim organisasi adalah,“ organizational climate is an overall "feeling" that is conveyed by the physical layout, the way participants interact, and the ways members of the organization conduct themselves with customers or other outsiders". Iklim organisasi adalah perasaan yang disampaikan oleh tata letak fisik, cara anggota berinteraksi dan cara mereka memahami organisasi dengan pegawai atau pihak luar lainnya. Kemudian Stephen P. Robbins dan Timothy A.Judge (2011:58), iklim organisasi adalah, "organizational climate refers to the shared perceptions organizational members have about their organization and work environment". Iklim organisasi merujuk pada persepsipersepsi bersama oleh anggota organisasi tentang organisasi dan lingkungan kerja mereka. Iklim organisasi menurut Rae Andre (2008:446) adalah, "climate to refer to organizational members perceptions of an organization's policies, practices, and procedures, including its structure, reward systems, warmth and support, and other aspects". Iklim merujuk kepada persepsi anggota organisasi akan kebijakan organisasi, praktek, dan prosedur, termasuk struktur, sistem penghargaan, kehangatan dan dukungan, dan aspek lainnya. Sedangkan menurut Laurie J Mullins (2005:899) pengaruh iklim organisasi adalah sebagai berikut: "organisational climate will influence the level of morale and attitudes which members of the organisation bring to bear on their work performance and personal relationships". Iklim organisasi akan mempengaruhi tingkat moral dan sikap yang anggota organisasi bawa untuk melahirkan kinerja kerja dan hubungan pribadi mereka. Moral adalah konsep umum yang sulit untuk mengukur secara obyektif. Sesuatu yang dirancang dengan cermat dan survey yang dilakukan dapat membantu untuk membangun perasaan pegawai pada faktor-faktor yang berkontribusi terhadap iklim organisasi. Ketika pegawai merasa moralnya rendah, dalam organisasi maka perasaan frustrasi atau keterasingan akan muncul pada pegawai, penting bahwa tindakan positif harus diambil untuk mengatasi penyebabnya. Moral dapat dilihat dari segi sikap mental orang terhadap tugas dan tanggung jawab.

Kemudian Laurie J Mullins (2011:900) mengidentifikasi iklim organisasi adalah "climate can be said to relate to the prevailing atmosphere surrounding the organization, to the level of morale, and to the strength of feelings or belonging, care and good will among members". Iklim dapat dikatakan berhubungan dengan suasana yang berlaku di sekitar organisasi, tingkat moral, dan kekuatan perasaan atau rasa memiliki, kepedulian dan niat baik di antara anggota. Taguiri dan Litwin dalam tulisan Hendayat Soetopo (2010:141) mendefinisikan iklim organisasi adalah suatu kualitas lingkungan internal organisasi yang dialami oleh anggotanya, mempengaruhi perilakunya, dan dapat dideskripsikan dengan nilai-nilai karakteristik organisasi. Richard M. Hodgetts yang dikutip Kondalkar (2007:343) mengelompokkan iklim organisasi menjadi dua faktor tersembunyi yaitu:(1)Overt factors (hierarchy, goals of the organization, financial resources, skills and abilities of employees, technological state of the organization, performance standards adopted, efficiency measurement), and (2) Covert factors (values, attitude, norms, feelings, interaction, supportiveness, satisfaction). Iklim organisasi dikelompokan menjadi dua faktor 
tersembunyi yaitu: (1). Faktor terbuka (overt factors), meliputi hirarki, tujuan organisasi, sumber keuangan, keterampilan dan kemampuan karyawan, kondisi teknologi organisasi, standar kinerja yang ditetapkan, ukuran efisiensi. (2) Faktor tersembunyi (covert factors) meliputi nilai, sikap, norma, perasaan, interaksi, dukung, dan kepuasan. Iklim organisasi menurut Sabine Sonnentag (2002:449) akan mempengaruhi tingkat sikap dan perilaku individu.

Maka sintesis iklim organisasi adalah suasana yang timbul dalam organisasi yang dapat dirasakan atau mempengaruhi sikap, tingkah laku anggota organisasi dalam melaksanakan tugasnya.

\section{Komitmen Organisasi ( X2).}

Menurut Richard L. Daft (2010:445), "organizational commitment is loyalty to and heavy involvement in one's organization". Komitmen organisasi adalah loyalitas seseorang terhadap keterlibatan yang sangat kuat dalam sebuah organisasi. Selanjutnya, Ricky W. Griffin and Gregory (2004:71)menjelaskan, "organizational commitment is a person's identification with and attachment to an organization". Komitmen organisasi adalah identifikasi seseorang dengan dan keterikatan pada organisasi.Penjelasan lain menurut John R Schermerhorn (2010:335), "organizational commitment is the loyalty of an individual to the organization". Komitmen organisasi adalah loyalitas individu terhadap organisasi. Mathis dan Jackson (2000) dalam Sopiah (2008:155) memberikan definisi "organizational commitment is the degree to which employees believe in and accept organizational goals and desire to remain with the organization. Fred Luthans (2008:147) mendefinisikan komitmen organisasi: "As an attitude, organizational commitment is most often defined as (1) a strong desire to remain a member of particular organization; (2) a willingness to exert high levels of effort on behalf of the organization, and (3) a definite belief in, and acceptance of, the values and goals of the organization. Sebagai sebuah sikap, komitmen organisasi paling sering didefinisikan sebagai (1) keinginan yang kuat untuk tetap menjadi anggota organisasi tertentu, (2) kemauan yang tinggi untuk selalu berupaya untuk kepentingan organisasi, dan (3) keyakinan yang pasti dan penerimaan, nilai-nilai dan tujuan organisasi. Lebih lanjut Stephen P. Robbins and Timothi A. Judge (2011:111) menyatakan, "organizational commitment the degree to which an employee identifies with a particular organization and its goals and wishes to maintain membership in the organization." Komitmen organisasi sejauh mana seorang karyawan mengidentifikasi dengan organisasi tertentu dan tujuan dan keinginan untuk mempertahankan keanggotaan dalam organisasi. Stephen P. Robbins and Timothi A. Judge (2011:111) sependapat dengan Fred Luthan (2008:148) menjelaskan. "There are three separate dimensions to organizational commitment; (1) Affective commitment is an emotional attachment to the organizational and a belief its values. (2) Continuance commitment is the perceived economic value of remaining with an organization. (3) Normative commitment is an obligation to remain with the organization for moral or ethical reasons. Ada tiga dimensi yang terpisah untuk komitmen organisasi; (1) komitmen afektif adalah keterikatan emosional dengan organisasi dan keyakinan nilai-nilainya. (2) komitmen kesinambungan adalah nilai ekonomi yang dirasakan dari yang tersisa dengan sebuah organisasi. (3) komitmen normatif adalah kewajiban untuk tetap dengan organisasi karena alasan moral atau etika.

Berdasarkan deskripsi konsep di atas dapat disintesiskan bahwa komitmen organisasi adalah loyalitas seseorang terhadap keterlibatan dirinya yang sangat kuat dalam sebuah organisasi. Loyalitas, keterlibatan dan keinginan yang kuat untuk tetap konsisten dalam organisasi dapat tertanam pada diri pegawai sehingga dapat memberikan kontribusi yang sangat positif dan dilakukan dengan sukarela. 


\section{METODE}

Metode yang digunakan adalah metode survey dengan unit analisis penelitian pegawai di lingkungan Dinas Pendidikan Kota Tangerang Provinsi Banten. Penelitian dilakukan selama 6 (enam) bulan dengan sampel penelitian sebanyak 65 responden diambil dengan menggunakan tehnik Simple Random Sampling. Tehnik pengumpulan data dilakukan dengan menggunakan kuesioner dengan skala penilaian (rating scale). Tehnik analisis data yang digunakan secara deskriptif dan inferensial yang digunakan untuk menguji hipotesis dengan menggunakan analisis jalur (path analysis).

\section{HASIL DAN PEMBAHASAN \\ Pengaruh Iklim Organisasi Terhadap Perilaku keanggotaan organisasional/ organizational citizenship behavior (OCB).}

Berdasarkan hasil perhitungan diperoleh koefisien korelasi r13=0,704 dan koefisien jalur p31 $=0,473$. Dengan demikian terdapat pengaruh langsung positif iklim organisasi terhadap perilaku keanggotaan organisasional/organizational citizenship behavior (OCB). Hal ini sesuai dengan teori yang dikemukakan oleh Laurie J Mullins mendefinisikan "organizational climate will influence the level of morale and attitudes which members of the organization bring to bear on their work performance and personal relationships". Iklim organisasi akan mempengaruhi tingkat moral dan sikap yang anggota organisasi bawa untuk melahirkan kinerja kerja dan hubungan pribadi mereka. Jika iklim organisasi sehat dan nyaman, pegawai akan lebih memperlihatkan perilaku positif yang melampaui tugasnya dengan kesadaran sendiri tanpa harus diperintah dan diingatkan kembali apa tugas dan kerjanya. Iklim yang baik dan sehat meningkatkan tingkat pelayanan para pegawai terhadap masyarakat. Jika seorang pegawai memiliki perasaan dan keyakinan tentang suasana yang ada dalam organisasi adalah menyenangkan, saling mempercayai, tidak adanya konflik, hubungan antar personal berjalan dengan baik, pekerjaan saling mendukung sehingga menjadi lancar. Ketika dukungan antara individu terjadi, maka akan berakibat pada kehangatan di dalam organisasi. . Kreitner dan Kinicki (2011:174) menyatakan, "organizational citizenship behavior (OCB) consist of employees behavior that are beyond the call of duty. Examples include "such as gestures as constructive statements about the department, expression of personal interest in the work of others, suggestions for improvement, training new people, respect for the spirit as well as the letter of housekeeping rules, care for organizational property, and punctuality and attendance well beyond standard or enforceable levels". OCB terdiri dari perilaku individu diluar tugas pekerjaannya. Seperti memberikan saran yang membangun, membantu meningkatkan sumber daya manusia, mengarahkan karyawan baru, menghormati ketentuanketentuan organisasi, peduli terhadap property organisasi serta berperilaku melebihi tingkat standar yang ditetapkan. Selain peran yang melampaui "panggilan tugas", Dimensi dari perilaku OCB yang tidak mengikat dan dilakukan dengan sukarela tanpa mengharapkan penghargaan. Laurie J. Mullins (2005:899) menjelaskan, "organisational climate will influence the level of morale and attitudes which members of the organisation bring to bear on their work performance and personal relationships". Iklim organisasi akan mempengaruhi tingkat moral dan sikap yang anggota organisasi bawa untuk melahirkan kinerja kerja dan hubungan pribadi mereka. Kondisi tersebut akhirnya memunculkan perilaku untuk membantu orang lain dalam hal pekerjaanya, taat pada 
peraturan organisasi, menghormati orang lain dan memiliki rasa tanggung jawab yang tinggi, maka yang terjadi akan meningkatkan perilaku keanggotaan organisasional/organizational citizenship behavior (OCB).

\section{Pengaruh Komitmen Organisasi terhadap Perilaku keanggotaan organisasional/ organizational citizenship behavior (OCB).}

Berdasarkan hasil perhitungan diperoleh koefisien korelasi r23=0,689 dan koefisien jalur p32=0,442. Dengan demikian terdapat pengaruh langsung Komitmen Organisasi terhadap perilaku keanggotaan organisasional/organizational citizenship behavior (OCB). Seperti yang dijelaskan Richard L. Daft (2010:445), "organizational commitment is loyalty to and heavy involvement in one's organization". Komitmen organisasi adalah loyalitas seseorang terhadap keterlibatan yang sangat kuat dalam sebuah organisasi. Menurut Fred Luthan (2008:147) komitmen organisasi didefinisikan sebagai sebuah sikap,(1). Keinginan yang kuat untuk tetap menjadi anggota organisasi tertentu, (2). Kemauan yang tinggi untuk selalu berupaya demi kepentingan organisasinya, dan (3).Keyakinan yang pasti dengan organisasi karena alas an moral atau etika. Ketika pegawai merasakan kenyamanan dan tanggung jawab karena tugas terhadap pekerjaanya maka pegawai tersebut akan bekerja maksimal dalam menyelesaikan pekerjaanya, bahkan melakukan beberapa hal yang mungkin diluar tugasnya. Begitu juga dengan ketika seseorang mempunya komitmen yang tinggi terhadap organisasinya, maka orang tersebut akan melakukan apapun untuk memajukan organisasinya karena keyakinannya terhadap organisasinya dan komitmen yang tinggi. Selanjutnya, Ricky W. Griffin and Gregory (2004:71) menjelaskan, "organizational commitment is a person's identification with and attachment to an organization". Komitmen organisasi adalah identifikasi seseorang dengan dan keterikatan pada organisasi. John R Schermerhorn (2010:335) menjelaskan, "organizational commitment is the loyalty of an individual to the organization". Komitmen organisasi adalah loyalitas individu terhadap organisasi. Mathis dan Jackson (2000) dalam Sopiah (2008:155) memberikan definisi "organizational commitment is the degree to which employees believe in and accept organizational goals and desire to remain with the organization. Fred Luthans (2008:147) mendefinisikan komitmen organisasi, "as an attitude, organizational commitment is most often defined as (1) a strong desire to remain a member of particular organization; (2) a willingness to exert high levels of effort on behalf of the organization, and (3) a definite belief in , and acceptance of, the values and goals of the organization. Sebagai sebuah sikap, komitmen organisasi paling sering didefinisikan sebagai (1) keinginan yang kuat untuk tetap menjadi anggota organisasi tertentu, (2) kemauan yang tinggi untuk selalu berupaya untuk kepentingan organisasi, dan (3) keyakinan yang pasti dan penerimaan, nilai-nilai dan tujuan organisasi. Jadi, komitmen organisasi berpengaruh langsung positif terhadap perilaku keanggotaan organisasional/organizational citizenship behavior (OCB).

\section{Pengaruh Iklim Organisasi terhadap Komitmen Organisasi.}

Berdasarkan hasil perhitungan dapat diperoleh koefisien korelasi r12=0,522 dan koefisien jalur p21=0,522. Dengan demikian terdapat pengaruh langsung positif iklim organisasi terhadap perilaku keanggotaan organisasional/organizational citizenship behavior (OCB).

Stephen P. Robbins dan Timothy A.Judge menjelaskan iklim organisasi adalah, "organizational climate refers to the shared perceptions organizational members have about their organization and work environment". Iklim organisasi merujuk pada persepsi-persepsi bersama oleh anggota anggota organisasi tentang organisasi dan lingkungan kerja mereka. Iklim merujuk kepada persepsi anggota organisasi akan kebijakan organisasi, 
praktek, dan prosedur, termasuk struktur, sistem penghargaan, kehangatan dan dukungan, dan aspek lainnya. Iklim organisasi menurut Rae Andre (2008:446) adalah, "climate to refer to organizational members perceptions of an organization's policies, practices, and procedures, including its structure, reward systems, warmth and support, and other aspects". Iklim merujuk kepada persepsi anggota organisasi akan kebijakan organisasi, praktek, dan prosedur, termasuk struktur, sistem penghargaan, kehangatan dan dukungan, dan aspek lainnya. Sedangkan Ketika seseorang memiliki perasaan, persepsi-persepsi yang baik terhadap lingkungan organisasinya tersebut dan memiliki rasa kepedulian serta niat baik terhadap teman sejawatnya maka secara otomatis akan memberikan dukungan terhadap individu yang lain. Kemudian jika komitmen yang muncul membutuhkan iklim organisasi yang kondusif maka iklim organisasi akan membuat kenyaman bagi anggota organisasi itu sendiri dan berpengaruh langsung terhadap keyakinan dan keterikatan diri anggota organisasi terhadap organisasinya.

\section{PENUTUP}

Kesimpulan. Berdasarkan hasil penelitian ini dapat disimpulkan bahwa: (1) Terdapat pengaruh langsung positif iklim organisasi terhadap perilaku keanggotaan organisasional/organizational citizenship behavior (OCB) ditentukan oleh derajat besarnya pengaruh dalam bentuk koefisien korelasi dan koefisien jalur. Nilai koefisien jalur menentukan besaran varians perilaku keanggotaan organisasional/organizational citizenship behavior (OCB) ditentukan oleh iklim organisasi. Selanjutnya dapat diketahui signifikansi pengaruh antara iklim organisasi terhadap perilaku keanggotaan organisasional/organizational citizenship behavior (OCB). Hal ini memiliki makna dan penegasan bahwa iklim organisasi secara empiris bukan satu-satunya variabel prediktor bagi varians skor perilaku keanggotaan organisasional/organizational citizenship behavior (OCB). (2) Terdapat pengaruh positif komitmen organisasi terhadap perilaku keanggotaan organisasional/organizational citizenship behavior (OCB) yang ditentukan oleh derajat besarnya pengaruh dalam bentuk koefisien korelasi dan koefisien jalur. Nilai koefisien jalur menentukan besaran varians perilaku keanggotaan organisasional/organizational citizenship behavior (OCB) ditentukan oleh komitmen organisasi. Selanjutnya dapat diketahui signifikansi pengaruh antara komitmen organisasi terhadap perilaku keanggotaan organisasional/organizational citizenship behavior (OCB) secara parsial. Hal ini memiliki makna dan penegasan bahwa organizational citizenship behavior (OCB) secara empiris bukan satu-satunya variabel prediktor bagi varians skor produktivitas. (3) Terdapat pengaruh positif iklim organisasi terhadap OCB.

Saran. Berdasarkan hasil penelitian beberapa hal yang disarankan bagi perwujudan dan peningkatan perilaku keanggotaan organisasional/organizational citizenship behavior (OCB) sebagai berikut: 1) Para pengambil keputusan hendaknya memperhatikan masalah iklim organisasi, dan komitmen organisasi dalam rangka meningkatkan perilaku keanggotaan organisasional/organizational citizenship behavior (OCB). Selain itu, ternyata masih banyak variabel lain yang berpengaruh langsung terhadap perilaku keanggotaan organisasional/organizational citizenship behavior (OCB) pegawai Dinas Pendidikan Kota Tangerang. Pemahaman tentang perilaku keanggotaan organisasional/organizational citizenship behavior (OCB) pegawai Dinas Pendidikan Kota Tangerang akan membantu para pengambil keputusan dalam mewujudkan tujuan organisasi bersama-sama dengan para pegawai lainnya. 2) Para pegawai Dinas Pendidikan Kota Tangerang hendaklah meningkatkan perilaku positif yaitu perilaku 
keanggotaan organisasional/organizational citizenship behavior (OCB) dalam menjalankan peranan dan tanggung jawab sebagai pegawai Dinas Pendidikan Kota Tangerang. Hal ini dapat dilakukan dengan peningkatan iklim organisasi, dan komitmen organisasi melalui upaya mengikuti pembinaan atau pelatihan yang diikuti oleh para pegawai Dinas Pendidikan. Diharapkan dengan peningkatan perilaku positif para pegawai maka berpengaruh terhadap peningkatan mutu pendidikan dengan mengembangkan sumber daya yang ada dengan efektif dan efisien.

\section{DAFTAR RUJUKAN}

Andre, Rae, Organizational Behavior, New Jersey : Pearson Prentice Hall, 2008

Colquitt, Jeffery A.Lepine, Michael J.Wesson, Organizational Behavior Improving Performance and Commitment in The Workplace, Second Edition, New York : McGraw Hill Irwin, 2009

Daft, Richard L. New Era of Management Cengage Learning: South-Wester, 2010

Griffin, Ricky. and Gregory. Organizational Behavior Managing people and New York: Houghton, 2007

Griffin, Ricky. Manajemen Jilid 2 alih bahasa Gina Ghania, terjemah Edisi 7 Jakarta: Erlangga, 2004.

Kreitner, Kinicki, Organizational Behavior, Ninth Edition, New York : McGraw Hill, 2010

Luthans, Fred, Organizational Behavior. An Evidence-Based Approach, Twelfth Edition, New York : McGraw-Hill, 2011

-------, Organizational Behavior Twelfth Edition, New York : McGraw-Hill, 2011

McShane dan Von Glinow, Organizational Behavior Emerging Knowledge and Practice For The Real World, New York : McGraw Hill, 2010

Organizational Behavior Third Edition, The McGraw Hill-Irwin,2004.

Mullins, Laurie J, Management and Organizational Behavior Seventh Edition, England : Financial Times, 2005

Organ, W, Dennis, Philip, M Podsakof, and Scott B, Mackenzie, Organizational Citizenship Behavior: Its Nature Anteceddents, and Consequances, USA: Sage Publications, Inc., 2006

Robbins Stephen P, dan Mary Coulter, Management, New Jersey : Prentice Hall, 2009

Robbins, Stephen P, dan Timothy A. Judge, Organizational Behavior Fourteenth Edition, New Jersey : Prentice Hall, 2011 
Schermerhorn, John R, JR, Introduction to Management Ten Edition, USA : John Wiley \& Sons, 2010

Sonnentag, Sabine, Psychologycal Management of individual performance a Handbook in the Psychology of Management in Organizations, New York : John Wiley and Sons. Ltd, 